\title{
Analysis of Toxicity in Endometrial Cells Exposed Phthalate
}

\author{
Jae-Sun Choi \\ Department of Biomedical Laboratory Science, Far East University, Eumseong, Korea
}

\section{자궁내막세포에 노출된 프탈레이트의 독성연구}

\author{
최재선 \\ 극동대학교 임상병리학과
}

\begin{abstract}
Di-ethylhexyl phthalate (DEHP) is an environmental contaminant that is used as a plasticizer. Endometriosis is a complex disease with an unknown etiology that is believed to be associated with exposure to DEHP. The present study examined the potential toxicity of DEHP by exposing endometrial adenocarcinoma cells (Ishikawa cells) to DEHP. In the experiments, the cells were treated with stepwise DEHP concentrations $(0,0.01,0.1,1$, and $5 \mu \mathrm{M})$ for different exposure times $(24,48$, and $72 \mathrm{~h})$. When the relationship between the resulting survival rate of the cells and initial inflammation was examined, the cell viability, expression of TNF- $\alpha$, an inflammatory mediator, and the expression of MMP-9, an ECM degradation protein, were increased remarkably when the cells were exposed to $5 \mu \mathrm{M}$ DEHP for 48 and 72 hours. These results suggest that the exposure of Ishikawa cells to certain concentrations of DEHP, estrogen mimics, may cause time-dependent toxicity that affects the cell viability and inflammation, implying a potential role in the etiology of endometriosis. Further research on the effects of endocrine disruptors on the pathogenesis of endometriosis may reveal strategies to prevent this disease.
\end{abstract}

Key words: Endocrine disruptor, Endometriosis, Phthalate (2-ethylhexyl phthalate, DEHP), TNF- $\alpha$, MMP-9

This is an Open Access article distributed under the terms of the Creative Commons Attribution Non-Commercial License (http://creativecommons.org/licenses/by-nc/4.0) which permits unrestricted non-commercial use, distribution, and reproduction in any medium, provided the original work is properly cited.

Copyright (C) 2019 The Korean Society for Clinical Laboratory Science. All rights reserved.
Corresponding author: Jae-Sun Choi Department of Biomedical Laboratory Science, Far East University, 76-32 Daehak-gil, Gamgok-myeon, Eumseong 27601, Korea Tel: 82-43-880-3891 Fax: 82-43-880-3876

E-mail: jaenny123@gmail.com ORCID: https://orcid.org/0000-0002-1733-4088

Received: January 2, 2019

Revised $1^{\text {st: }}$ January 28, 2019

Revised $2^{\text {nd }}$ : February 12,2019

Accepted: February 22, 2019

\section{서 론}

자궁내막증(endometriosis)은 estrogen에 의존하는 염증성 질환으로 병인은 잘 알려져 있지 않으며, 생물학적 특성은 침윤 과 전이능을 갖는 암세포와 유사하다[1]. 내분비 장애 물질인 프 탈레이트(2-ethylhexyl phthalate, DEHP)는 estrogen 유사 물질로 자궁내막증과 연관이 있을 것으로 추측하여 관련 증거 들을 여러 방면으로 넓여가고 있다.

산업화 이후 화학물질의 합성은 급속도로 늘어나 현재 그 종 류만 수십만 종에 이르며 2016년 EC (European Commision) 전문위원회에서 업데이트한 최종 보고서에는 146 여종의 내분
비 장애 물질(endocrine disrupting chemicals)들을 제시하고 있다[2]. 내분비 장애 물질은 체내 호르몬 교란을 일으켜 생식 계, 내분비 및 대사와 관련한 여러 질환에 영향을 미치는 것으로 알려진다[3].

$\mathrm{DEHP}$ 는 플라스틱에 유연성을 부여하는 가소제로 장난감, 학용품, 향수, 화장품, 빨대, 의료용 지퍼백 등의 다양한 산업 제 품에 사용된다[4]. 이러한 제품들은 일상생활에서 쉽게 접할 수 있어 호흡기 및 피부와의 접촉을 통해 연속적인 DEHP 노출로 이어질 수 있다 [5]. DEHP는 화학 구조상 플라스틱 matrix에 공 유결합하지 않으므로 주변 환경에 서서히 유출될 수 있고, 식품, 음료 그리고 체액으로 서서히 침투할 수 있다[6]. 실제 DEHP는 
공기, 물 그리고 토양에서도 검출되고 있다[7]. 이렇게 DEHP는 다방면의 경로를 통해 생물학적 농축으로 증폭되어 인체에 고 농도로 유입될 수 있다[8].

Table 1에 제시한 프탈레이트계 내분비 장애 물질들은 estrogen과 유사한 작용을 하는 물질이다. 내분비 장애 물질과 estrogen 의존성인 자궁내막증에 관한 연구들은 이미 1990년 부터 보고되기 시작하였다[9]. 임상의 사례에서는 자궁내막증 을 가지는 환자의 $92 \%$ 가 혈장에서 $\mathrm{DEHP}$ 의 농도가 높게 검출 되어 DEHP의 노출과 자궁내막증은 연관성이 있는 것으로 보고 한 바 있다[10]. 그러나 DEHP의 노출과 자궁내막증의 직접적 인 관계에 대해서는 아직 알려진 것이 없으므로 병인을 알아가 기 위해서는 보다 지속적인 연구가 필요한 실정이다. 세포는 외 부 환경인 독성이나 유해물질에 노출되면 생체내 광범위 하게 퍼져 있는 tumor necrosis factor alpha (TNF- $\alpha$ )를 통하여 생 존, 분화, 그리고 세포 사멸 등의 다양한 형태로 세포를 조절한 다[11]. TNF- $\alpha$ 는 염증, 면역 및 암 발생에 작용하는 중요한 염 증성 사이토카인으로 vascular endothelial growth factor (VEGF)를 유도하여 신생 혈관을 촉진 시킬 수 있고, matrix metalloproteinases (MMPs)를 유도하여 종양 침윤과 전이에 도 관여할 수 있다[12, 13].

$\mathrm{MMPs}$ 는 단백분해효소 그룹으로 분해 조직에 따라 5 군으로 구분한다. 이 중 gelatinase에 속하는 MMP-2와 MMP-9은 collagen으로 구성된 기저막(basement membrane)과세포외 기질(extracellular matrix, ECM)을 파괴하는데 중요한 역할 을 담당한다. 염증성 cytokine TNF- $\alpha$ 가 Ishikawa cell을 자극 하여 $\mathrm{MMPS}$ 를 분비하고 기저막과 $\mathrm{ECM}$ 에 침착 되는 구성요소를 분해하기 위해 MMPs의 활성이 일어난다. MMP-9은 MMP-2와 비슷한 구조를 보이고 조직의 remodeling에도 관여한다고 한다 [14]. 특히, MMP-9의 발현 증가는 혈관 형성, 침윤 및 전이를 포 함하는 염증성 병리에 관여하는 것으로 보고된다[13, 15].

이에 본 연구에서는, 환경 유해물질이자 내분비 장애 물질인 DEHP의 노출이 Ishikawa cell에 미치는 독성을 조사하고자 하 였다.

\section{재료 및 방법}

\section{1. 화학 약품}

DEHP는 Sigma-Aldrich (Merck KGaA, Darmstadt, Germany)에서 구매하여 사용하였다.

\section{2. 세포주 및 세포 배양}

본 연구에 사용된 Ishikawa cell은 서울 의과대학으로부터 분양 받아 10\% FBS (Gibco, Thermo Fisher Scientific, Inc., Waltham, MA, USA)가 포함된 Dulbecco's modified Eagle's 배지(DMEM, Gibco)에 항생제를 첨가하여 $37^{\circ} \mathrm{C}, 5 \% \mathrm{CO}_{2}$ 배 양기에서 배양하였다.

\section{DEHP 농도 및 노출시간}

본 실험에 사용된 DEHP의 농도는 [16]의 보고에 따라 환자 의 혈장에서 나타난 수치를 참조하여 5 단계 0 (대조군), 0.01, $0.1,1,5 \mu \mathrm{M}$ 로 결정하였고 노출 시간은 $24 \sim 72$ 시간 시행하였 다.

\section{MTT assay}

세포 생존율을 확인하기 위해 MTT assay (Cell Titer 96 ${ }^{\circledR}$ AQueous Cell Proliferation Assay kit; Promega Corporation, Madison, WI, USA)를 실시하였다. 방법을 간략하게 서 술 하자면 Ishikawa cell을 5단계 DEHP 농도로 처리한 후 24, 48,72 시간 동안 배양하였다. 배양한 후, $100 \mu \mathrm{L}$ 배양 배지에 20 $\mu \mathrm{L} /$ well MTT (3-(4,5-Dimethylthiazol-2-yl)-2,5-diphenyl tetrazolium bromide) 용액을 첨가하여 $37^{\circ} \mathrm{C}$ 에서 4 시간 연속 배양한 시점에서 microplate reader를 사용하여 $490 \mathrm{~nm}$ 에서 흡광도를 측정하였다.

\section{Real time PCR; RNA 추출 및 $\mathrm{CDNA}$ 합성}

Trizol Reagent ${ }^{\mathrm{TM}}$ (Invitrogen, Thermo Fisher Scientific Inc. MA, USA)를 사용하여 DEHP 처리하여 배양한 Ishikawa cell에서 total RNA를 추출하고, Transcription First Strand cDNA Synthesis kit (Roche)를 사용하여 각각의 샘플 $1 \mu \mathrm{g}$

Table 1. Suspected endocrine disrupting chemicals

\begin{tabular}{cccc}
\hline Substance category & Name & Source/uses & Reported properties \\
\hline $\begin{array}{c}\text { Industrial Chemicals and } \\
\text { related Substance }\end{array}$ & $\begin{array}{c}\text { Phthalates (DEHP, BBP, } \\
\text { DBP, DPP, DPrP) }\end{array}$ & $\begin{array}{c}\text { Use as plasticisers in the } \\
\text { production of flexible plastics }\end{array}$ & Estrogenic \\
\hline
\end{tabular}

Abbreviations: DEHP, di(2-ethylhexyl)phthalate; BBP, benzyl butyl phthalate; DBP, dibutyl phthalate; DPP, di-n-pentyl phthalate; DPrp, di-propyl phthalate. 
total RNA로부터 cDNA를 합성하였다. Real-time PCR 증폭은 SYBR Green master mix (Applied Biosystems, Foster City, $\mathrm{CA}$ )와 함께 Step One Plus Real-Time PCR System (Applied Biosystems)을 사용하여 합성된 $\mathrm{cDNA}$ 를 template 삼아 염증 단백질 TNF- $\alpha$ 유전자 발현을 위해 희석된 cDNA $6.75 \mu \mathrm{L}, 10$ $\mu \mathrm{L}$ SYBR green master mix (Thermo Fisher Scientific Inc.), Forward and Reverse primer 각각 10 pmol, nuclease-free water $4 \mu \mathrm{L}$ 포함된 $45 \mu \mathrm{L}$ PCR amplification master mix를 $20 \mu \mathrm{L}$ 씩 2개의 PCR tube에 분배한 후 실시하였다. TNF- $\alpha$ 및 house keeping 유전자 GAPDH에 사용된 primer 서열은 Table 2에 언급하였고 TNF- $\alpha$ 에 대한 thermal profile은 $95^{\circ} \mathrm{C}$ 에서 1 분간 initial denaturation, $95^{\circ} \mathrm{C}$ 에서 30 초간 denaturation, $50^{\circ} \mathrm{C}$ 에서 30 초간 annealing, $72^{\circ} \mathrm{C}$ 에서 30 초간 extension을 40 cycle 수행 후 측정 하였다. 상대적인 mRNA 값은 표준화된 $\mathrm{GAPDH}$ 유전자 값을 control 수치로 정하여 comparative cycle threshold ( $\triangle \triangle \mathrm{Ct}$ ) 방법을 사용하여 계산 하였다.

\section{Western blot analysis}

$\mathrm{DEHP}$ 처리한 세포 $\left(1 \times 10^{6} / \mathrm{per} \mathrm{mL}\right)$ 를 수거하여 RIPA buffer (50 mM Tris; pH 8.0; Cell Signaling, USA)로 용해하였고, 용 해된 세포액을 원심 분리시켜 상층액을 Pierce BCA protein assay kit로 측정하였다. 총 단백질 $40 \mu \mathrm{g}$ 을 $10 \% \mathrm{SDS}$-PAGE에

Table 2. Primers sequence and annealing temperature used for RT-PCR amplication

\begin{tabular}{ccc}
\hline Gene & Primer sequence & $\begin{array}{c}\text { Annealing } \\
\text { temp. }\left({ }^{\circ} \mathrm{C}\right)\end{array}$ \\
\hline THF- $\alpha$ & $\begin{array}{l}\text { Forward; 5'-GCTCACCCATTTCAACCAGT-3' } \\
\text { Reverse; 5'-CACAGAGCAGCTTGACTTGC-3' }\end{array}$ & 50 \\
GAPDH & $\begin{array}{l}\text { Forward; 5'-TGGGCTACACTGAGCACCAG-3' } \\
\text { Reverse; 5'-GGGTGTCGCTGTTGAAGTCA-3' }\end{array}$ & 55 \\
\hline
\end{tabular}

Abbreviation: RT-PCR, real-time polymerase chain reaction.
전기영동 하였고 그 후 nitrocellulose 막으로 이전하였다. $5 \%$ skimmed milk로 실온에서 $2 \mathrm{~h}$ 동안 blocking 한 후 3회 세척 하였다. 1차 항체(MMP-9 (1:1,000), $\beta$-actin (1:5,000), all Cell Signaling Technology, Inc.)로 $4^{\circ} \mathrm{C}$ 에서 하룻밤 반응시킨 후 TBST로 3번 세척 하였고 2차 항체(Goat anti mouse IgGHRP-IgG (1:5,000, Invitrogen)로 실온에서 $2 \mathrm{~h}$ 반응시킨 후 세척 하였다. 세척 후 Pierce enhanced chemiluminescence detection substrate (Thermo Fisher Scientific, Inc.)을 이용 하여 단백질 밴드를 확인하였다.

\section{7. 통계학적 분석}

모든 실험은 최소 3회 이상 반복 실시하였으며, 측정한 모든 데이터는 Mean $\pm \mathrm{SD}$ 로 표시하였다. 통계 처리는 통계프로그램 (SPSS version 14.0, SPSS, Inc., Chicago, IL, USA)으로 실시하 였다. 분석에 대한 유의성은 $\mathrm{ANOVA}$ 를 이용하여, $P<0.05$ 이하인 경우를 유의성이 있는 것으로 판정하였다.

\section{결 과}

\section{DEHP 노출이 세포 생존에 미치는 영향}

Ishikawa cell에 DEHP를 노출 시킨 후 세포 생존율에 미치 는 영향을 알아보기 위해 MTT assay를 시행하였다. 단계별 $\mathrm{DEHP}$ 농도 $(0,0.01,0.1,1,5 \mu \mathrm{M})$ 로 $24,48,72$ 시간 노출한 후 대조군과 비교하여 세포 생존율을 확인하였다. $0.01,0.1 \mu \mathrm{M}$ $\mathrm{DEHP}$ 농도로 24,48 시간 노출 후에 나타난 결과는 대조군과 비 교하여 유의적인 세포 생존율을 나타내지 않았으나, $1,5 \mu \mathrm{M}$ $\mathrm{DEHP}$ 농도로 72 시간 노출한 후 대조군과 비교하였을 때는 5 $\mu \mathrm{M} \mathrm{DEHP}$ 농도에서만 현저하게 증가한 세포 생존율을 나타내 었다 $(P<0.05)$ (Figure 1).

\section{DEHP 노출과 염증성 사이토카인 TNF- $\alpha$ 의 발현}

세포 생존율 결과에 이어 초기 염증을 유도하는 염증성 사이

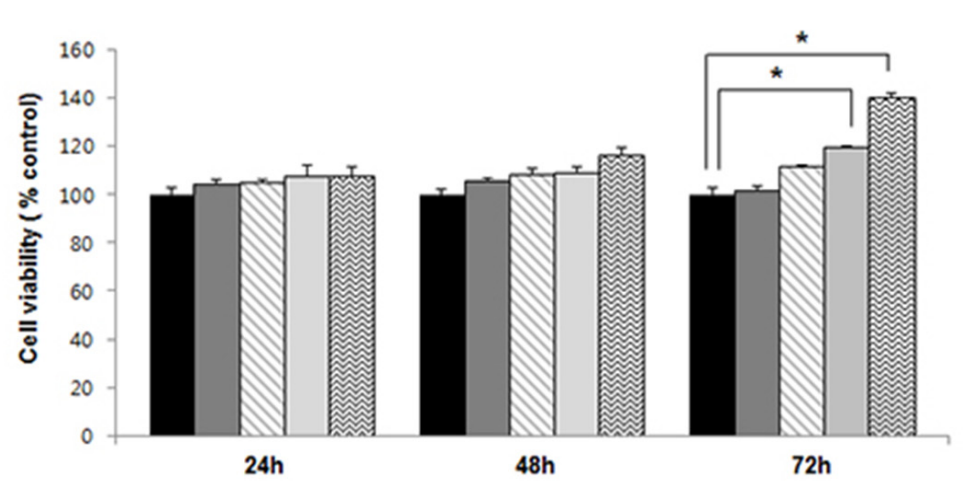

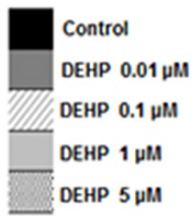

Figure 1. Viability of Ishikawa cells after exposure to DEHP. Cells were exposed to $0,0.01,0.1,1$, or $5 \mu \mathrm{M}$ DEHP for 24,48 or 72 hour. Data were presented as the mean \pm standard deviation. ${ }^{*} P<0.05$. DEHP, di(2-ethylhexyl) phthalate; Bar graph showing percentage of cell viability. 
토카인 생성을 알아보기 위해 $\mathrm{mRNA}$ 를 추출하여 TNF- $\alpha$ 의 발 현 양상을 살펴보았다. TNF- $\alpha$ 의 발현은 Figure 1에 제시한 것 처럼 현저한 세포 생존율을 보이는 $5 \mu \mathrm{M} \mathrm{DEHP} \mathrm{농도에서만} \mathrm{실}$ 험하였다. $5 \mu \mathrm{MDEHP}$ 농도로 24 시간 노출하였을 때 TNF- $\alpha$ 의 발현은 대조군과 비교하여 증가하였으나 유의하지 않은 것으로 나타났다. 그러나 48시간과 72 시간 노출 후에는 대조군과 비교 하여 현저하게 증가하였다. 48시간과 72 시간 노출 후를 비교하 여 보면 48시간에 비해 72시간 노출 후에는 TNF- $\alpha$ 의 발현이 증가한 것으로 관찰되었다(Figure 2).

\section{DEHP의 노출과 $M M P-9$ 의 발현}

$\mathrm{MMP}-9$ 의 발현 또한 $5 \mu \mathrm{M} \mathrm{DEHP} \mathrm{농도에서만} \mathrm{western} \mathrm{blot}$

TNF- $\mathbf{\alpha}$

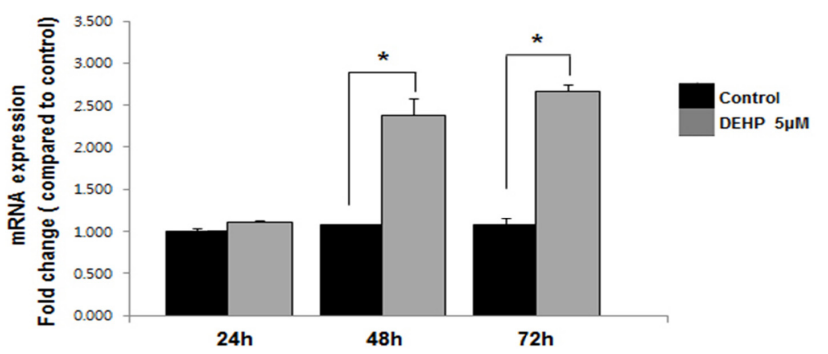

Figure 2. Effects of in vitro DEHP treatment on inflammation in Ishikawa cells. TNF- $\alpha$ mRNA was quantified by real-time-PCR and data were expressed as fold expression over average of gene expression in BSA treated cells. Data were shown as mean \pm standard deviation of three independent experiments. ${ }^{*} P<0.05$. TNF- $\alpha$, tumor necrosis factor $-\alpha$. High expression of TNF- $\alpha$ compared to control was induced with $5 \mu \mathrm{M}$ DEHP at $48 \mathrm{~h}$ and $72 \mathrm{~h}$ exposed in cell.
을 통하여 확인하였다. $5 \mu \mathrm{M} \mathrm{DEHP} \mathrm{농도로} \mathrm{24시간} \mathrm{노출} \mathrm{후에}$ 대조군과 비교하여 MMP-9의 발현은 증가하였으나 유의하지 않은 것으로 나타났다. 그러나 48시간과 72시간 노출 후에는 대 조군과 비교한 MMP-9의 발현은 현저하게 증가하는 것으로 나 타났다. 48시간과 72시간 노출 후를 비교하여 보면 48시간에 비해 72시간 노출 후에는 MMP-9의 발현이 더 증가한 것으로 나타났다 $(P<0.05) . \mathrm{MMP}-9$ 의 발현 또한 시간-의존적으로 증 가하는 패턴을 보였다. 단백질의 발현량 수치는 대조군 $\pm \mathrm{SD}$ 에 비례한 평균 변화치로 $\beta$-acin에 비례하여 계산하였다(Figure 3).

\section{고 찰}

생활에서 편리하게 쓰이는 플라스틱 제품의 급격한 소비는 생태계를 오염시키는 유해물질로 재인식되고 있다. DEHP는 플라스틱 제품을 통해 주변 환경으로 노출될 수 있고, 노출된 $\mathrm{DEHP}$ 는 인체에 서서히 침투하여 축적될 수 있음을 보고하고 있다[8]. 여전히 DEHP의 잠재적 독성에 대한 우려는 생식계를 비롯한 신경계 및 발암 유발까지 인체의 건강에 심각한 문제를 주고 있다. DEHP의 노출은 유방암세포에서는 세포 증식을 [17], 신경모세포종에서는 침윤 촉진을[18], 간암 세포에서는 세포 생존율을 증가시키는 것으로 보고된다[19]. 또한 in vitro 에서 염증성 사이토카인 생산을 증가시킨다[20].

이번 연구에서는 DEHP의 노출이 Ishikawa cell에 미치는 독 성을 조사하였다. 우리의 연구 결과는 DEHP의 노출은 노출 시 간에 의존하여 Ishikawa cell의 생존율 증가, 염증성 사이토카

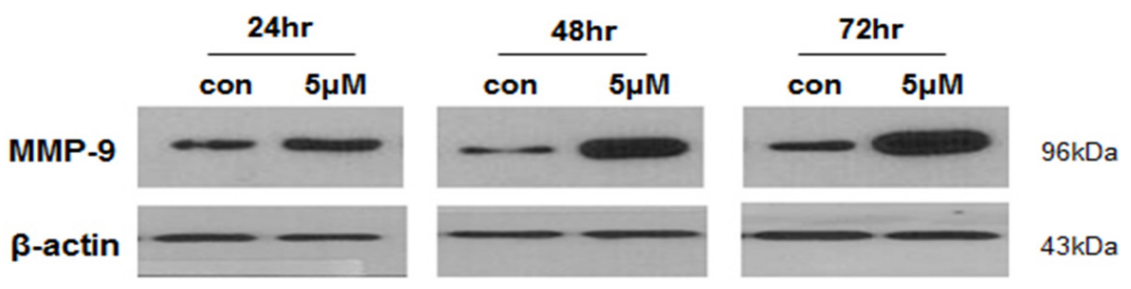

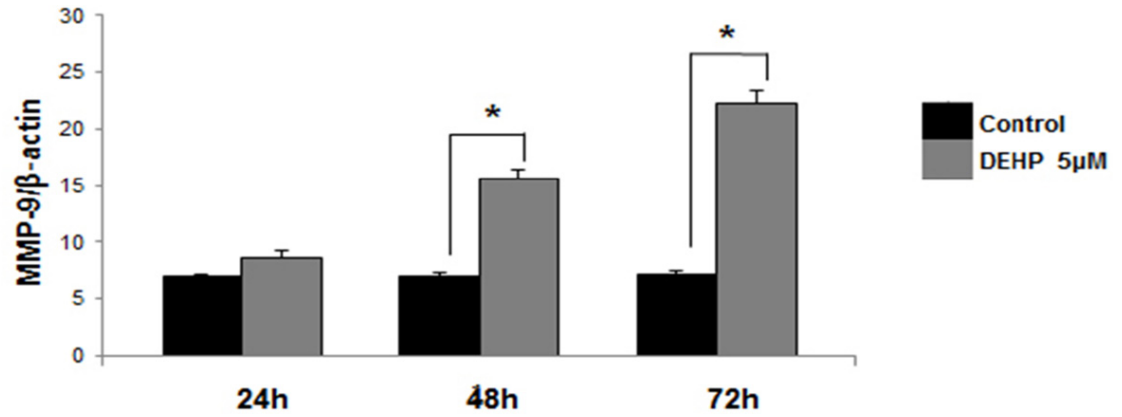

Figure 3. Effects of in vitro DEHP treatment on proliferation of Ishikawa cells. MMP-9 expression levels in Ishikawa cells were measured by western blot analysis. Western blot data were expressed as percentages, with cells treated with vehicle normalized to $100 \%$. Data were presented as the mean \pm standard deviation. ${ }^{*} p<0.05$. DEHP, di-(2-ethylhexyl) phthalate; MMP 9, matrix metalloproteinase-9. 
인 TNF- $\alpha \mathrm{mRNA}$ 의 발현 증가 그리고 $\mathrm{ECM}$ 을 분해하는 MMP-9 의 발현이 증가하는 것으로 나타났다. 이러한 결과들은 $\mathrm{DEHP}$ 의 노출이 Ishikawa cell에 독성으로 작용하고 있고 이러한 독성은 자궁내막증에 잠재적인 역활을 할 수 있을 것으로 보여진다.

Kim 등[21]의 보고에 따르면 DEHP의 노출은 estrogen에 영 향 받는 Ishikawa cell의 생존율을 증가시킨다고 보고하고 있 다. 본 연구에서도 DEHP가 유해물질임에도 불구하고 Ishikawa cell의 생존율을 유의적으로 증가시켰다. 이러한 결과는 에스트 로겐 유사 작용을 가지는 $\mathrm{DEHP}$ 가 호르몬 교란을 일으키는 것 으로 추측한다. 호르몬 교란은 신호전달 과정 중 세포사멸을 우 회 할 수 있다는 가설로 지속적인 DEHP의 노출은 활성화된 $\mathrm{NF}-\kappa \mathrm{B}$ 신호전달 경로를 통해 간세포에서 세포 증식을 촉진 시 킬 수 있다고 하였고[22], NF-kB의 발현이 자극 물질을 통해 신 호전달 과정 중 우회하여 감소되면 apoptosis를 억제할 수 있다 고 보고하고 있다[23]. 다른 하나는 염증성 사이토카인과 관련 한 분극화를 통해 생존율에 기여할 수도 있을 것으로 추측하고 있다. 만성 염증들과 비슷하게 암과 연계된 염증은 종양 주변을 둘러싼 미세환경을 관장하므로 세포 분화와 생존율 등에 기여 한다[24]. 종양 관련 마크로파지(Tumor-associate macrophages, TAM)의 분극화는(M1, M2 형질) TAM이 가지고 있는 표현형을 변화시켜 생존에 도움을 주기도 한다[25]. Bolling 등 에 의하면 MEHP 노출은 TNF- $\alpha$ 방출을 증가시켜 RAW264.7 cell 안에서 세포 형태가 항염증성 M2 형질로 바뀌었음을 제시 하기도 하였다[26]. 향 후 DEHP의 노출과 세포 생존율이 증가 하는 것을 밝히기 위해서는 내분비 교란을 통한 신호전달 기전 이 정확히 밝혀져야 명확한 해석을 할 수 있을 것으로 판단된다.

$\mathrm{TNF}-\alpha$ 는 활성화된 대식세포에서 주로 생성되는 cytokine 으로 염증, 면역조절, 그리고 세포 분화에 중요한 역할을 하는 것으로 알려져 있다[27, 28]. TNF- $\alpha$ 와 IL-8 같은 cytokines들 은 자궁내막 및 자궁내막세포를 성장-촉진시키는 효과를 가지 고 있다고 한다[29]. 이미 많은 임상의 연구를 통해 자궁내막증 이 있는 여성의 복강액에 TNF- $\alpha$ 가 상승되어 있다고 하였다. 이 러한 TNF- $\alpha$ 의 증가는 ECM 성분과 자궁내막 간질 사이의 부착 을 증가시킬 수 있다고 암시하였다[30]. 본 연구에서도 실험에 서 설정한 최고 $5 \mu \mathrm{M} \mathrm{DEHP}$ 농도를 Ishikawa cell에 노출 시켰 을 때 TNF- $\alpha$ RNA 발현이 시간-의존적으로 증가하고 있음을 확인하였다. 자궁내막증의 중요한 일반 개념은 복강내 환경에 서 면역 관련 세포의 기능이 변경된 국소 골반 염증 과정으로 [30] 가장 중요한 TNF- $\alpha$ 가 국소적이고 체계적인 발현에 중심 역할을 하는 것으로 입증되었다[31, 32]. 2018년 Peng의 보고 에 따르면[33] 자궁내막증 진행과정에서 케모카인과 염증 유발
성 cytokine 수치의 상승에 관여하는 염증 기전의 활성화는 더 욱 분명해져 자궁내막증 환자에서 RT-qPCR을 통한 TNF- $\alpha$ $\mathrm{mRNA}$ 발현과 단백질 발현을 조사하여 제시하기도 하였다. 본 실험에서 24 시간 DEHP 노출은 TNF- $\alpha$ 발현에 유의적인 결과 를 보이지 않았으나 48시간에서 72 시간 동안의 DEHP 노출은 TNF- $\alpha$ 발현이 대조군에 비해 현저히 증가하고 있는 것으로 미 루어 볼 때 초기 염증 유발 후 TNF- $\alpha$ 의 자극을 통해 더 많은 $\mathrm{TNF}-\alpha$ 를 생산하는 것으로 보여진다. 이는 DEHP의 노출이 Ishikawa cell에 TNF- $\alpha$ 를 발현시켜 초기 염증을 유발시키고 노출 시간이 지남에 따라 더 증가하는 TNF- $\alpha$ 환경을 조성하는 것으로 생각한다. TNF- $\alpha$ 의 다면적 역할을 고려한다면 다방면 의 연구가 가능할 것으로 판단된다. MMPs family 중 MMP-9은 기저막과 세포외기질(extracellular matrix, ECM)을 분해를 하는 gelatinase로 다양한 병리 기전에 관여한다[13]. MMP-9 의 발현은 염증 초기에 백혈구에서 관찰되고 사이토카인이나 케모카인에 의해 유도 발현되며[34] 정상 조직에서는 낮은 수준 으로 발현되거나 발현되지 않는 것으로 보고된다[35]. 그러나 Rodgers 등[36] 연구진들의 보고에 의하면 파괴와 복구를 거듭 하는 정상 자궁내막에서는 지속적으로 MMPs 발현이 나타남을 제시하였다. 반면 유방암 등의 다양한 종양에서는 현저하게 증 가하는 발현율을 보이며[37], 혈장 내에 상승 발현한 MMP-9은 침윤 또는 전이와 상관 관계가 있는 것으로 보고하였다[38]. 본 연구에서 실험에 설정한 최고 $5 \mu \mathrm{M} \mathrm{DEHP} \mathrm{농도를} \mathrm{Ishikawa}$ cell에 노출시켰을 때 MMP-9의 발현은 시간-의존적으로 증가 함을 확인하였다. TNF- $\alpha$ 는 강력한 신생혈관 유도제로[39] 비 정상 주기를 갖는 여성에서 estrogen은 자궁내막에 혈관생성 인자를 증가시킬 수 있으므로 MMP-2와 MMP-9의 발현을 향 상시킬 수 있다고 보고하고 있다[40]. 따라서 DEHP가 estrogen 유사물질임을 감안하면 DEHP 노출에 의해 Ishikawa cell에서 MMP-9을 증가시키는 것으로 보여진다. 다른 한편, 현 실험에 서는 MMP-9의 활성형과 비활성을 구분하지 않은 관계로 기능 에 대한 구체적인 언급은 할 수 없지만 TNF- $\alpha$ 발현을 통한 염증 유발로 인해 기저막과 $\mathrm{ECM}$ 에 축적된 임시 구성요소들을 분해 할 수도 있다고 여겨진다.

결론적으로 이번 연구에서는 DEHP가 Ishikawa cell에 노출 되면 노출 시간과 농도에 의해 세포에 독성물질로 작용하여 세 포의 생존율을 증가시키고, 염증성 사이토카인 TNF- $\alpha$ mRNA, MMP-9의 발현이 증가됨을 확인하였다. 향후 세포사멸 우회 기 전, 염증성 사이토카인의 다면적 역할 등 DEHP의 독성 작용과 자궁내막증과의 연관성에 관한 추가 연구가 필요할 것으로 사 료된다. 


\section{요 약}

프탈레이트(2-ethylhexyl phthalate, DEHP)는 환경오염 물질 중 하나이며 플라스틱 가소제로 사용된다. 자궁내막증 (endometriosis)은 병인이 잘 알려지지 않는 복잡한 질환으로 estrogen 유사 작용을 하는 DEHP 노출과 연관성이 있을 것으 로 추측하고 있다. 이에 본 연구는 DEHP를 Ishikawa cell에 노 출시켜 Ishikawa cell에 미치는 잠재적 독성을 조사하여 자궁 내막증의 병인 연관성을 알아보고자 하였다. 실험은 DEHP 농 도 $(0,0.01,0.1,1,5 \mu \mathrm{M})$ 를 단계적으로 처리하여 시간별 $(24$, $48,72 \mathrm{~h}$ )로 노출하였고 이에 따른 세포의 생존율, 염증 반응 그 리고 $\mathrm{ECM}$ 분해 단백질과의 관계를 살펴본 결과 $5 \mu \mathrm{M} \mathrm{DEHP}$ 농 도에서 $48,72 \mathrm{~h}$ 노출하였을 때 세포 생존율와 염증성 사이토카 인 TNF- $\alpha$ 그리고 ECM 분해 단백질 MMP-9의 발현이 시간 의 존적으로 증가함을 확인하였다. 이러한 결과는 일정 농도 이상 에서의 estrogen 유사 물질인 DEHP 노출이 Ishikawa cell에 노출 시간에 의존하여 독성으로 작용하면서 세포 생존율 증가 와 염증에 영향을 주어 자궁내막증의 병인에 잠재적인 역할을 할 수 있음을 암시한다. 향후 자궁내막증의 발병 기전에 내분비 교란 물질이 미치는 영향을 연구하여 자궁내막증 예방을 위한 전략을 제시할 것이다.

Acknowledgements: This work was supported by the 2018 Far East University Research (FEU 2018R25).

Conflict of interest: None

Author's information (Position): Choi JS, Assistant professor.

\section{REFERENCES}

1. Shaco-Levy R, Sharabi S, Benharroch D, Piura B, Sion-Vardy N. Matrix metalloproteinases 2 and 9, E-cadherin, and beta-catenin expression in endometriosis, low-grade endometrial carcinoma and non-neoplastic eutopic endometrium. Eur J Obstet Gynecol Reprod Biol. 2008;139:226-232.

2. Kortenkamp A, Martin O, et al. State of the art assessment of endocrine disruptors. Final Report. Brussels: European Commission; 2011

3. Diamanti-Kandarakis E, Bourguignon JP, Giudice LC, Hauser R, Prins GS, Soto AM, et al. Endocrine-disrupting chemicals: an endocrine society scientific statement. Endocr Rev. 2009;30: 293-342.

4. Halden RU. Plastics and health risks. Annu Rev Public Health. 2010;31:179-194. https://doi.org/10.1146/annurev.publhealth. 012809.103714 .
5. Centers for Disease Control and Prevention. Fourth national report on human exposure to environmental chemicals [Internet]. Atlanta: Center for Disease Control and Prevention; 2012 [cited Jan 02]. Available from: http://www.cdc.gov/exposurereport/ pdf/fourthreport.pdf.

6. Maryam ZJ, Masud Y, Reza A, Noushin R. Effect of sunlight exposure on phthalates migration from plastic containers to packaged juices. J Environ Health Sci Eng. 2018;16:292 http: doi.org/10.1007/s40201-018-0292-8.

7. Xia X, Yang L, Bu Q, Liu R. Levels, distribution, and health risk of phthalate esters in urban soils of Beijing, China. J Environ Qual. 2011;40:1643-1651.

8. Zolfaghari M, Drogui P, Seyhi B, Brar SK, Buelna G, Dube R. Occurrence, fate and effects of Di (2-ethylhexyl) phthalate in wastewater treatment plants: a review. Environ Pollut. 2014; 194:281-293.

9. Rier S, Foster WG. Environmental dioxins and endometriosis. Toxicol Sci. 2002;70:161-170.

10. Cobellis L, Latini G, De Felice C, Razzi S, Paris I, Ruggieri F, et al. High plasma concentrations of di-(2-ethylhexyl)-phthalate in women with endometriosis. Hum Reprod. 2003; 18:1512-1515.

11. Park H, Kim BS. Effect of fucoidan on angiogenesis and gene expression in human umbilical vein endothelial cells. Korean J Clin Lab Sci. 2017;49:323-328.

12. Rosen EM, Goldberg ID, Liu D, Setter E, Donovan MA, et al. Tumor necrosis factor stimulates epithelial tumor cell motility. Cancer Res. 1991;51:5315-5321.

13. Egeblad M, Werb Z. New functions for the matrix metalloproteinases in cancer progression. Nat Rev Cancer. 2002; 2:161-174.

14. Ramos-DeSimone N, Hahn-Dantona E, Sipley J, Nagase H, French DL, Quigley JP. Activation of matrix metalloproteinase9 (MMP-9) via a converging plasmin/stromelysin-1 cascade enhances tumor cell invasion. J Biol Chem. 1999;274:1306613076.

15. Parks WC, Wilson CL, Lopez-Boado YS. Matrix metalloproteinases as modulators of inflammation and innate immunity. Nat Rev Immunol. 2004;4:617-629.

16. Durmaz E, Ozmert EN, Erkekoglu P, Giray B, Derman O, Hincal F, et al. Plasma phthalate levels in pubertal gynecomastia. Pediatrics. 2010;125:122-129.

17. Chen FP, Chien MH. Lower concentrations of phthalates induce proliferation inhuman breast cancer cells. Climacteric. 2014; 17:377-384.

18. Zhu H, Zheng J, Xiao X, Zheng S, Dong K, Liu J, et al. Environmental endocrine disruptors promote invasion and metastasis of SK-N-SH human neuroblastoma cells. Oncol Rep. 2010;23:129-139.

19. Chen X, Qin Q, Zhang W, Zhang Y, Zheng H, Liu C, et al. Activation of the PI3K-Akt-mTor signaling pathway promotes DEHP-induced Hep3b cell proliferation. Food Chem Toxicol. 2013;59:325-333.

20. Jepsen KF, Abildtrup A, Larsen ST. Monophthalates promote IL-6 and IL-8 production in the human epithelial cell line A549. Toxicol In Vitro. 2004;18:265-269. http://doi:10.1016/j.tiv. 2003.09.008.

21. Kim YH, Kim SH, Lee HW, Chae HD, Kim CH, Kang BM. 
Increased viability of endometrial cells by in vitro treatment with di-(2-ethylhexyl) phthalate. Fertil Steril. 2010;94:24132416.

22. Wei N, Feng X, Xie Z, Zhang Y, Feng Y. Long-term di(2-ethylhexyl)-phthalate exposure promotes proliferation and survival of HepG2 cells via activation of NFkB. Toxicol In Vitro. 2017;42:86-92.

23. Vaskivuo TE, Stenbäck F, Tapanainen JS. Apoptosis and apoptosis-related factors Bcl-2, Bax, tumor necrosis factor $\alpha$, and NF$\kappa \mathrm{B}$ in human endometrial hyperplasia and carcinoma. Cancer. 2002;95:1463-1471.

24. Ungefroren H, Sebens S, Seidl D, Lehnert H, Hass R. Interaction of tumor cells with the microenvironment. Cell Commun Signal. 2011;9:1-8.

25. Qian BZ, Pollard JW. Macrophage diversity enhances tumor progression and metastasis. Cell. 2010;141:39-51.

26. B ølling AK, Ovrevik J, Samuelsen JT, Holme JA, Rakkestad KE, Mathisen GH, et al. Mono-2-ethylhexylphthalate (MEHP) induces TNF- $\alpha$ release and macrophage differentiation through different signaling pathways in RAW264.7 cells. Toxicol Lett. 2012;209:43-50.

27. Lebovic DI, Mueller MD, Taylor RN. Immunobiology of endometriosis. Fertil Steril. 2001;75:1-10.

28. Weiss G, Goldsmith LT, Taylor RN, Bellet D, Taylor HS. Inflammation in reproductive disorders. Reprod Sci. 2009;16:216-229.

29. Ulukus M, Arici A. Immunology of endometriosis. Minerva Ginecol. 2005;573:237-248.

30. Harada T, Iwabe T, Terakawa N. Role of cytokines in endometriosis. Fertil Steril. 2001;76:1-10.

31. Iwabe T, Harada T, Tsudo T, Nagano Y, Yoshida S, Tanikawa M, et al. Tumor necrosis factor-alpha promotes proliferation of endometriotic stromal cells by inducing interleukin- 8 gene and protein expression. J Clin Endocrinol Metab. 2000;85:824-829.

32. Eisermann J, Gast MJ, Pineda J, Odem RR, Collins JL. Tumor necrosis factor in peritoneal fluid of women undergoing laparoscopic surgery. Fertil Steril. 1988;50:573-579.

33. Peng Y, Ma J, Lin J. Activation of the CXCL16/CXCR6 Axis by TNF-a contributes to ectopic endometrial stromal cells migration and invasion. Reprod Sci. 2018;1:1-8.

34. Van den Steen PE, Dubois B, Nelissen I, Rudd PM, Dwek RA, Opdenakker G. Biochemistry and molecular biology of gelatinase B or matrix metalloproteinase-9 (MMP-9). Crit Rev Biochem Mol Biol. 2002;37:375-536.

35. Eisen NH. General immunology. 2nd ed. Philadelphia: JB Lippincot; 1980.

36. Rodgers WH, Matrisian LM, Giudice LC, Dsupin B, Cannon P, Svitek C, et al. Patterns of matrix metalloproteinase expression in cycling endometrium imply differential functions and regulation by steroid hormones. J Clin Invest. 1994;94:946-953.

37. Jones JL, Glynn P, Walker RA. Expression of MMP-2 and MMP-9, their inhibitors, and the activator MT1-MMP in primary breast carcinomas. J Pathol. 1999;189:161-168.

38. Wu CY, Wu MS, Chiang EP, Chen YJ, Chen CJ, Chi NH. Et al. Plasma matrix metalloproteinase-9 level is better than serum matrix metalloproteinase-9 level to predict gastric cancer evolution. Clin Cancer Res. 2007;13:2054-2060.

39. Leibovich SJ, Polverini PJ, Shepard HM, Wiseman DM, Shively V, Nuseir N. Macrophage-induced angiogenesis is mediated by tumor necrosis factor-a. Nature. 1987;329:630-632.

40. Zhang X, Qi C, Lin J. Enhanced expressions of matrix metalloproteinase (MMP)-2 and -9 and vascular endothelial growth factors (VEGF) and increased microvascular density in the endometrial hyperplasia of women with anovulatory dysfunctional uterine bleeding. Fertil Steril. 2010;93:2362-2367. 